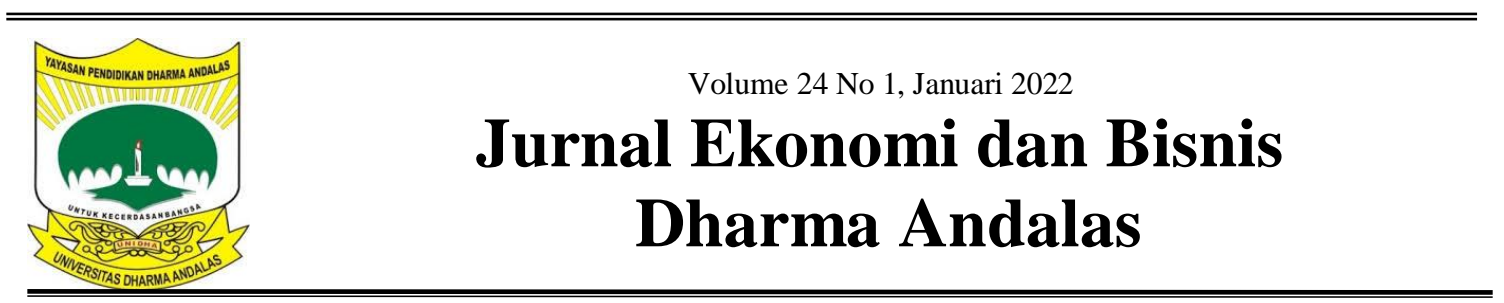

\title{
Analisis Keakuratan Prediksi Financial Distress
}

\author{
Sari Octavera ${ }^{1,}$ Aristia Syafel ${ }^{2}$ \\ Fakultas Ekonomi Dan Bisnis Universitas Dharma Andalas ${ }^{1,2}$ \\ e-mail : sarioctavera@gmail.com ${ }^{1}$ \\ aristya.syafel@gmail.com ${ }^{2}$
}

\begin{abstract}
This research is a descriptive research with a quantitative approach. The sampling technique used purposive sampling technique with 11 metal and similar sub-sector companies are listed on the Indonesia Stock Exchange (IDX) for the Q2 2018-Q2 2020 period as samples. The method used in this study is the Paired sample T test to see the differences between to the groups of models in predicting financial distress, and the result show that the Altman Z-Score-Zmijewski, Altman_Z_Score - Grover, Springate - Zmijewski, Grover-Zmijewski models have differences in predicting financial distress. Grover-Springate models has no differences predicting financial distress by looking at the Asymp value. Sig (2-tailed). Classify companies that experience financial distress and that do not experience financial distress as seen from the achievement of company profits that are positive categorized as companies that do not experience financial distress, and the other way companies that have negative profits are categorized as experiencing financial distress. Calculated the accuracy level of the model used in predicting financial distress and obtained the highest level of accuracy is owned by the Grover model with a value of $81.82 \%$ while the lowest level of accuracy is owned by the Altman Z-Score model with a value of $36.36 \%$. Keywords : financial distress, accuracy, altman z-score, grover, zmijewski dan springate
\end{abstract}

\begin{abstract}
ABSTRAK
Penelitian ini merupakan penelitian deskriptif dengan pendekatan kuantitatif. Teknik penarikan sampel yang digunakan adalah teknik pusposive sampling, maka didapatkan 11 perusahaan subsektor logam dan sejenisnya yang terdaftar di Bursa Efek Indonesia (BEI) periode Q2 2018Q2 2020 sebagai sampel. Metode yang digunakan dalam penelitian ini adalah Paired Sample T Test untuk melihat perbedaan antar dua kelompok model dalam memprediksi financial distress, dan didapatkan hasil bahwasanya model Altman Z-Score-Zmijewski, Altman_Z_Score - Grover, Springate - Zmijewski, Grover - Zmijewski memiliki perbedaan dalam memprediksi financial distress sementara model Grover - Springate tidak memiliki perbedaan dalam memprediksi financial distress dengan melihat nilai Asymp. Sig. (2-tailed). Pengklasifikasian perusahaan yang mengalami financial distress dan perusahaan yang tidak mengalami financial distress yang dilihat dari pencapaian laba perusahaan yang bernilai positif dikategorikan kepada perusahaan yang tidak mengalami financial distress, dan sebaliknya perusahaan yang memiliki laba negatif dikategorikan mengalami financial distress. Kemudian dilakukan perhitungan tingkat akurasi dari model yang digunakan dalam memprediksi financial distress dan didapatkan tingkat akurasi tertinggi dimiliki oleh model Grover dengan nilai $81,82 \%$ sedangkan tingkat akurasi yang terendah dimiliki oleh model Altman Z-Score dengan nilai 36,36\%.
\end{abstract}

Keywords : financial distress, keakuratan, Altman Z-Score, grover, zmijewski, springate 


\section{PENDAHULUAN}

Pentingnya pengukuran kinerja perusahaan dapat dijelaskan dengan dua teori yaitu agency theory dan signalling theory. Pada teori agensi dijelaskan bahwasanya ada dua pihak yang saling berinteraksi yaitu pemegang saham dan manajemen perusahaan, maka diperlukan proporsi pengaturan hak dan kewajiban masing-masing untuk menghindari konflik kepentingan (Jensen dan Meckling, 1976), kesepakatan tersebut diharapkan dapat memaksimumkan utilitas pemilik, dan dapat memuaskan serta menjamin manajemen untuk menerima reward atas hasil pengelolaan perusahaan.

Teori kedua yang menjelaskan pentingnya pengukuran kinerja adalah teori signal (signalling theory). Teori signal membahas bagaimana seharusnya signal- signal keberhasilan atau kegagalan manajemen (agen) disampaikan kepada pemilik (principal). Teori signal menjelaskan bahwa pemberian signal dilakukan oleh manajemen untuk mengurangi informasi asimetris. salah satu caranya adalah dengan memberikan signal kepada pihak luar berupa informasi keuangan yang dapat dipercaya sehingga dapat mengurangi ketidakpastian mengenai prospek perusahaan pada masa yang akan datang. Informasi tersebut merupakan unsur yang sangat penting bagi investor dan pemangku kepentingan lainnya, karena di dalam informasi tersebut menjelaskan mengenai keterangan, catatan, maupun gambaran perusahaan baik di masa lalu maupun di masa depan (ugene F. Brigham 2014).

Teori sinyal dalam topik financial distress menjelaskan bahwa jika kondisi keuangan dan prospek perusahaan baik, manajer memberi sinyal dengan menyelenggarakan akuntansi liberal. Sebaliknya, jika perusahaan dalam kondisi financial distress dan mempunyai prospek yang buruk, manajer memberi sinyal dengan menyelenggarakan akuntansi konservatif. Oleh karena itu, teori sinyal digunakan untuk memberikan sinyal kepada para manajer tentang informasi yang baik dan buruk bagi perusahaan agar seorang manajer dapat mengambil tindakan atau langkah cepat dalam menyelesaikan masalah khususnya masalah kesulitan keuangan (financial distress) yang timbul di suatu perusahaan.

Platt dan Platt (2002) dalam (Junaedy and Yanti 2019) menyatakan kegunaan informasi jika suatu perusahaan mengalami financial distress adalah: 1 . Dapat mempercepat tindakan manajemen untuk mencegah masalah sebelum terjadinya kebangkrutan. 2. Pihak manajemen dapat mengambil tindakan merger atau takeover agar perusahaan lebih mampu untuk membayar hutang dan mengelola perusahaan dengan baik. 3. Memberikan tanda peringatan awal adanya kebangkrutan pada masa yang akan datang

Perang dagang yang terjadi antara Amerika Serikat dengan China mengenai tarif bea masuk antar sesama merupakan salah satu konflik perekonomian yang menyeret perekonomian dunia menjadi melemah. Perang dagang Amerika dan China yang di mulai pada tahun 2018 lalu membuat perekonomian dunia menjadi tidak stabil dan cenderung menagalami penurunan secara menyeluruh. Menurut International Monitery Bank pada CNBC Oktober 2019 di kutip pada pengumuman besaran tarif akan membuat pertumbuhan perekonomian dunia mengalami penurunan 0,8 persen (Fauzia 2019). Belum lagi kondisi perekonomian membaik, timbul lagi pandemi Coronavirus Disease 2019 (COVID-19) yang menyerang ratusan negara di dunia. Pandemi yang muncul pertama kali di kota Wuhan, Provinsi Hubei, Tiongkok pada 1 Desember 2019, hingga saat ini sudah menyerang kurang lebih dari 210 
negara di dunia, dengan kurang lebih 64.188.964 kasus positif yang di laporkan (Koesno 2020). Akibat yang di timbulkan oleh pandemi ini tidak hanya menyerang kesehatan masyarakat di berbagai negara, namun juga menyerang perekonomian dunia. Penutupan usaha dan beberapa kegiatan produksi yang tidak berhubungan dengan produksi barang konsumsi dan kebutuhan pangan lainnya, tidak hanya harga komoditas yang menurun namun juga daya beli masyarakat juga melemah akibat adanya pandemi ini. Perdagangan secara global anjok sekitar 18,5 persen dari biasanya (Abrar 2020).

Indonesia merupakan salah satu negara yang terkena dampak dari kasus tersebut, sektor vital perekonomian Indonesia mengalami dampak negatif khususnya yang dirasakan oleh perusahaan yang ada di Indonesia, baik Badan Usaha Milik Negara (BUMN) maupun perusahaan milik swasta. Dalam menjalankan kegiatan produksi banyak perusahaan yang mengandalkan impor bahan baku dari luar negeri hal ini dilakukan karena tidak tersedianya bahan baku sampai kualitas bahan baku yang dibutuhkan tidak tersedia di dalam negeri, sehingga pembelian bahan baku dari luar negeri akan memberikan dampak yang cukup signifikan dikarenakan pelemahan harga rupiah menjadikan biaya yang dikeluarkan oleh perusahaan lebih banyak dari sebelumnya, tidak hanya itu kondisi pandemi Covid-19 yang menyebabkan kurangnya permintaan karena menurunnya daya beli masyarakat dan pembatasan kegiatan selama pandemi Covid-19 yang membuat kegiatan produksi dan pembangunan terhambat, sehingga berdampak pada perusahaan perusahaan yang ada di Indonesia, salah satunya perusahaan yang bergerak dibidang industri dasar dan kimia. Perusahaan ini bergerak di bidang industri manufaktur. Perusahaan pada sektor industri manufaktur merupakan salah satu perusahaan terbanyak yang ada di Indonesia, sedangkan untuk perusahaan pada sektor industri dasar dan kimi a yang listing di BEI ada 9 subsektor dan salah satunya adalah sub sektor logam dan sejenisnya. Dampak dari kondisi perekonomian saat ini sangat berimbas pada perusahaan pada sektor industri kimia dasar, pada Jumat 28 Februari 2020 penurunan indeks yang di alami sektor ini mencapai 21,24 persen (Sari 2020)

Melemahnya kinerja perusahaan membuat pendapatan menurun sehingga laba yang dihasilkan tidak bisa memenuhi kebutuhan operasional perusahaan. Tidak hanya itu, dampak yang sangat besar juga dapat berimbas pada kemampuan perusahaan dalam membayarkan kewajiban baik kewajiban jangka panjang maupun kewajiban jangka pendeknya, dengan demikian kesulitan keuangan akan melanda perusahaan, akibatnya perusahaan akan mengalami financial distress. Kondisi financial distress pada perusahaan akan memberi kecemasan dari berbagai pihak baik pihak internal maupun pihak eksternal.

\section{Laporan Keuangan Perusahaan}

Laporan keuangan dapat di artikan sebagai dokumen yang memberikan informasi pencatatan dari segala transaksi yang berkaitan dengan uang, pembelian dan penjualan serta kredit (Harmony 2020). Laporan Keuangan juga berguna untuk memberikan informasi mengenai posisi keuangan, kinerja keuangan dan arus kas perusahaan yang bermanfaat untuk bagian internal perusahaan ataupun bagian eksternal dari perusahaan itu sendiri. Bagian internal perusahaan yakni manajemen, karyawan dan pemilik perusahaan guna mengambil keputusan bisnis, sedangkan bagian eksternal merupakan investor, bank dan 
masyarakat yang memiliki kebutuhan akan laporan keuangan perusahaan.

Laporan keuangan perusahaan yang disajikan merupakan bentuk pertanggung jawaban dari manajemen perusahaan kepada kepada pihak-pihak yang berkepentingan pada perusahaan. Laporan keuangan adalah bagian dari proses pelaporan keuangan yang lengkap biasanya meliputi laporan posisi keuangan, laporan laba rugi, laporan posisi keuangan yang dapat di sajikan dalam berbagai cara, misalnya : sebagai laporan arus kas dan laporan lain serta materi penjelasan yang merupakan bagian integral dari laporan keuangan.

\section{Analisis Laporan Keuangan}

Analisis laporan keuangan menurut Harahap adalah menguraikan pos-pos laporan keuangan menjadi unit informasi yang lebih kecil dan melihat hubungannya bersifat signifikan atau yang mempunyai makna antara satu dengan yang lain baik antara data kuantitatif maupun yang tidak dengan tujuan untuk mengetahui kondisi keuangan lebih dalam yang sangat penting dalam proses menghasilkan keputusan yang tepat (Harahap Syafitri 2013).

Analisis laporan keuangan perlu dilakukan karena sangat bermanfaat bagi para analis untuk dapat mengetahui keadaan dan perkembangan keuangan dari perusahaan. Manajemen perusahaan sangat membutuhkan analisis laporan keuangan untuk mengetahui keadaan dan perkembangan perusahaan yang dipimpinnya. Manajemen dapat dengan mudah mengetahui pencapaian yang telah diraih pada masa lalu yang sedang berjalan sehingga dapat menentukan tindakan yang akan diambil untuk masa yang akan datang.

\section{Kesulitan Keuangan (Financial Distress)}

Beams mendefinisikan financial distress sebagai kegagalan usaha yang merupakan keadaan yang tidak muncul secara tiba-tiba, ketidakmampuan untuk memenuhi kewajibannya pada saat jatuh tempo (Beams 2015). Financial Distress juga dimaksudkan sebagai suatu keadaan atau situasi di mana perusahaan mengalami kekurangan dan ketidakcukupan dana untuk menjalankan atau melanjutkan usahanya. Perusahaan akan mengalami financial distress jika arus kas operasi perusahaan tidak mampu mencukupi pemenuhan kewajiban jangka pendek seperti pembayaran bunga kredit yang telah jatuh tempo. Semakin besar kewajiban yang dimiliki perusahaan akan menyebabkan semakin besarnya resiko terjadinya financial distress.

Financial distress juga dapat dikatakan sebagai penurunan kondisi keuangan perusahaan sebelum terjadinya kebangkrutan ataupun likuidasi. Salah satu mengindikasikan kondisi keuangan perusahaan dalam keadaan distress adalah ketidakmampuan perusahaan dalam membiayai operasional usaha disebabkan minimnya pemasukan dari produksi. Oleh karena itu perusahaan harus memastikan keuangan bagus, baik dari segi neraca maupun laporan laba rugi dalam laporan keuangan demi meminimalisir terjadinya financial distress.

Financial distress terjadi sebelum kebangkrutan pada suatu perusahaan, oleh karena itu setiap perusahaan harus melakukan prediksi financial distress karena kondisi kesulitan keuangan ini mungkin akan membantu perusahaan mengetahui kondisi kesehatan perusahaan yaitu kondisi kebangkrutan 
perusahaan. Salah satu faktor yang mengakibatkan perusahaan mengalami kebangkrutan adalah kondisi ekonomi suatu negara.

\section{Metode Analisis Financial Distress Model Altman Z-Score}

Rumus Z-Score untuk memprediksi kebangkrutan perusahaan yang pertama kali dipublikasi oleh Edward I. Altman di Amerika Serikat pada tahun 1968 (Hantono 2019), Edward I. Altman mengunakan analisis ini untuk melakukan prediksi terhadap perusahaan yang akan mengalami kebangkrutan dalam 2 tahun berikutnya. Dalam penelitiannya Altman menggunakan 5 rasio keuangan yakni rasio likuiditas, rasio profitabilitas, rasio leverage, rasio solvabilitas dan rasio aktivitas. Dari penelitian yang dilakukan oleh Altman didapatkan rumus sebagai berikut :

$$
\begin{aligned}
& Z=0,717 X_{1}+0,847 X_{2}+3,107 X_{3}+0,42 X_{4} \\
& +0,998 X_{5}
\end{aligned}
$$

Keterangan :

$\mathrm{X}_{1}$ :Working Capital / Total Asset

$\mathrm{X}_{2}$ : Retained Earning / Total Asset

$\mathrm{X}_{3}$ :Earning Before Interst And Taxes / Total Asset

$\mathrm{X}_{4}$ : Book Value Of Euity / Book Value Of Total Debt

$\mathrm{X}_{5}$ :Sales / Total Asset

Metode Altman Z-Score melihat jika nilai $\mathrm{Z}<1,8$ maka perusahaan mengalami kesulitan keuangan, jika nilai $\mathrm{Z}$ antara 1,81 - 2,99 perusahaan dikatakan dalam masa kondisi kritis dalam keuangannya, dan nilai $\mathrm{Z}>2,99$ Perusahaan dikatakan sehat dan tidak ada kemungkinan mengalami kesulitan keuangan atau financial distress.

\section{Model Grover}

Model grover diciptakan dengan melakukan pendesainan dan penilaian ulang terhadap model altman Z-score. Jeffrey S. Grover menggunakan sampel sesuai dengan model Altman Z-score pada tahun 1968 dengan menambahkan 13 rasio keuangan baru (Hantono 2019).
Nama model analisis ini di ambil dari nama penemunya, yakni Grover. Dalam menemukan rumus untuk analisis ini pada tahun 1982 Grover melakukan penelitian kepada 70 perusahaan sebagai sampel, dari penelitian tersebut terdapat 35 perusahaan yang mengalami kebangkrutan dan 35 perusahaan yang tidak bangkrut atau dalam keadaan sehat. Dari penelitian yang dilakukan oleh Grover ditemukan rumus berikut :

$G=1,650 X_{1}+3,404 X_{2}-0,016 X_{3}+0,057$

Keterangan :

$\mathrm{X}_{1}$ :Working Capital / Total Asset

$\mathrm{X}_{2}$ : Retained Earning / Total Asset

$\mathrm{X}_{3}:$ Return On Assets

Hasil dari analisa grover ini akan menunjukan perusahaan dalam keadaan bangkrut jika nilai $\mathrm{G}<$ atau $=-0,02$, untuk perusahaan dalam keadaan sehat ditandai dengan nilai $\mathrm{G}$ atau $=0,01$.

\section{Model Zmijewski}

Model Zmijewski ditemukan oleh Zmijewski pada tahun 1983 dengan melakukan riset selama 20 tahun dalam kurun waktu 1972 sampai dengan 1978 dalam (Supriati, Bawono, and Anam 2019). Dalam menemukan rumus ini Zmijewski menggunakan 143 perusahaan sebagai sampel, dimana ada 75 perusahaan dalam kondisi sehat dan 73 perusahaan dalam kondisi bangkrut, sehingga dalam hasil penelitian Zmijewski perbedaan antara perusahaan yang tidak bangkrut dan perusahaan yang bangkrut sangat terlihat. Dari penelitian yang dilakukan oleh Zmijewski ditemukan rumus berikut :

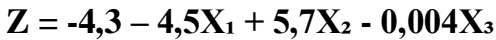

Keterangan :

$\mathrm{X}_{1}$ : Return On Assets

$\mathrm{X}_{2}$ : Debt Ratio

$\mathrm{X}_{3}$ : Current Ratio

Hasil dari analisa Zmijewski dapat menentukan kesulitan keuangan perusahaan jika nilai dari $\mathrm{Z}>$ atau $=$ dengan 0 , namun jika nilai $\mathrm{Z}$ suatu 
perusahaan < dari 0 maka perusahaan diprediksi dalam keadaan sehat.

\section{Model Springate}

Model Springate ditemukan oleh Gorgon L.V Springate pada tahun 1978. Model analisis springte ini merupakan rumus model rasio multiple discriminant analysis. Rumus springate yang digunakan (Yuliastary and Wirakusuma 2014) adalah sebagai berikut

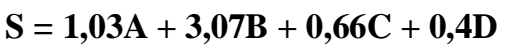

Keterangan :

A : Working Capital to Total Assets

B : Earning Before Interest and Taxes to

Total Assets

C : Earning Before Taxes to Current

Liabilities

D : Sales to Total Assets

Analisa model Springate menunjukan perusahaan dalam menilai kesulitan keuangan sebuah perusahaan jika nilai dari $\mathrm{S}<$ dari 0,862 , namun jika nilai perusahaan $>0,862$ perusahaan di prediksi dalam keadaan sehat.

\section{METODE PENELITIAN}

Jenis penelitian ini adalah penelitian deskriptif dengan pendekatan kuantitatif, menurut (Sugiyono 2018) adalah penelitian yang dilakukan untuk nilai variable mandiri dengan menggunakan pendekatan statistik namun tanpa membuat perbandingan atau hubungan dengan variable lainnya. Data yang dipakai dalam penelitian ini adalah data sekunder berupa laporan keuangan pada perusahaan subsektor logam dan sejenisnya yang terdaftar di BEI periode Q2 2018 - Q2 2020. Populasi penelitian ini merupakan seluruh perusahaan subsektor logam dan sejenisnya yang terdaftar di BEI periode Q2 2018 - Q2 2020.

Pengambilan sampel dengan metode purposive sampling, penulis mengambil kriteria sebagai berikut :
1. Perusahaan subsektor logam dan sejenisnya yang terdaftar di Bursa Efek Indonesia (BEI) periode Q2 2018-Q2 2020.

2. Perusahaan subsektor logam dan sejenisnya yang mempublikasikan laporan keuangan secara berturutturut selama periode Q2 2018-Q2 2020.

Sampel yang digunakan pada penelitian dengan menggunakan teknik purposive sampling adalah sebagai berikut :

\section{Tabel 1}

Kriteria Sampel Dengan Metode Purposive Sampling

\begin{tabular}{|c|c|c|}
\hline No & Kriteria & Jumlah \\
\hline 1 & $\begin{array}{l}\text { Perusahaan subsektor logam dan sejenisnya } \\
\text { yang terdaftar di Bursa Efek Indonesia (BEI) } \\
\text { periode Q2 2018-Q2 2020. }\end{array}$ & 17 \\
\hline 2 & $\begin{array}{l}\text { Perusahaan subsektor logam dan sejenisnya } \\
\text { yang tidak mempublikasikan laporan keuangan } \\
\text { secara berturut - turut selama periode Q2 2018- } \\
\text { Q2 } 2020\end{array}$ & (6) \\
\hline & Total & 11 \\
\hline
\end{tabular}
dilakukan apakah data yang digunakan terdistribusi normal atau tidak, dan selanjutanya akan dilakukan pengujian hipotesis menggunakan uji Paired Sample T Test dimana dengan metode pengujian ini akan terlihat tingkat perbedaan dari model dalam memprediksi financial distress. Kemudian perhitungan tingkat keakuratan model dalam memprediksikan financial distress dengan tahapan yang akan digunakan mengelompokkan perusahaan yang mengalami financial distress dan non financial distress dengan melihat perusahaan yang memiliki laba positif dan negative kemudian menghitung tingkat keakuratan model dengan rumus sebagai berikut (Mulyani et al. 2018) : Setelah dilakukan perhitungan dengan rumus keakuratan seperti berikut : 
Keakuratan $=\frac{\text { Jumlah Prediksi Benar }}{\text { Jumlah sampel }} \times 100 \%$

HASIL DAN PEMBAHAAN

Uji Statistik Deskrptif

Tabel 2.

Statistik Deskriptif

\begin{tabular}{lccccc}
\hline \multicolumn{1}{c}{ Model } & $\mathrm{N}$ & Minimum & Maximum & Mean & $\begin{array}{c}\text { Std. } \\
\text { Deviation }\end{array}$ \\
\hline $\begin{array}{l}\text { Altman Z- } \\
\text { Score }\end{array}$ & 99 & -0.21 & 110.22 & 8.9057 & 23.63489 \\
Grover & 99 & -1.74 & 3.81 & 0.9394 & 1.39271 \\
Zmijewski & 99 & -4.31 & 0.97 & - & 1.46833 \\
Springate & 99 & -0.43 & 4.22 & .6924 & 0.69801 \\
Valid N & 99 & & & & \\
(listwise) & & & & & \\
\hline Sumber: Hasil Pengolahan Data & & & & & \\
\hline
\end{tabular}

Sumber: Hasil Pengolahan Data,2021

\section{Uji Normalitas}

Tabel 3. Uji Normalitas

One-Sample Kolmogorov-Smirnov Test

\begin{tabular}{|c|c|c|c|c|c|}
\hline & & $\begin{array}{l}\text { Altman } \\
\text { Z-Score }\end{array}$ & Grover & $\begin{array}{c}\text { Zmijews } \\
\text { ki }\end{array}$ & Springate \\
\hline $\mathrm{N}$ & & 99 & 99 & 99 & 99 \\
\hline Normal & Mean & 8.9057 & .9394 & -1.9688 & .6924 \\
\hline \multirow[t]{2}{*}{ Parameters ${ }^{a, b}$} & Std. & 23.6348 & 1.39271 & 1.46833 & .69801 \\
\hline & Deviation & 9 & & & \\
\hline Most Extreme & Absolute & .456 & .162 & .125 & .129 \\
\hline \multirow[t]{2}{*}{ Differences } & Positive & .456 & .162 & .107 & .129 \\
\hline & Negative & -.350 & -.116 & -.125 & -.120 \\
\hline Test Statistic & & .456 & .162 & .125 & .129 \\
\hline Asymp. Sig. (2-tailed) & & $.060^{c}$ & $.090^{c}$ & $.071^{c}$ & $.0650^{c}$ \\
\hline
\end{tabular}

Sumber: Hasil Pengolahan Data,2021

$$
\text { Uji normalitas dengan }
$$

menggunakan uji One Sample

Kolmogorov-Smirnov mengatakan

bahwa nilai signifikansi lebih besar dari taraf signifikansi 0.05 sehingga dapat disimpulkan bahwa data sudah terdistrribsi normal. Uji normalitas dilakukan untuk menilai sebaran data apakah sudah berdistriburi normal atau tidak yang diambil dari populasi yang normal.
Hasil perhitungan dari 99 data di atas dapat terlihat bahwa terdapat perbedaan signifikan pada standart deviation yang dimiliki oleh Altman ZScore, hal ini dikarenakan nilai maket value of equity to book value of total debt pada perusahaan mencapai nilai tertinggi yakni 110.22257, angka dari perhitungan rasio tersebut juga menjadi nilai maximum tertinggi pada perhitungan financial distress dari keempat model, sedangkan untuk nilai terendah -4.31 pada perhitungan financial distress model Zmijewski dikarenakan nilai cut off yang menyatakan perusahaan dalam keadaan sehat jika nilai $\mathrm{Z}<0$ dan nilai -4.31 tersebut ada pada perusahaan KRAS pada kuartal keempat tahun 2019.

\section{(1) \\ Hasil Uji Hipotesis Penelitian}

\section{Uji Paired Sample T Test}

Pada uji paired sample t test ini melihat dari nilai Asymp. Sig. (2-tailed), jika nilai Asymp. Sig. (2-tailed) > 0.05, maka tidak terdapat perbedaan yang signifikan antara dua kelompok sampel. Namun bila probabilitas $<0.05$, maka terdapat perbedaan yang signifikan antara dua kelompok sampel (Mulyani et al. 2018). 
Berikut hasil pengolahan data uji paired sample t test yang dilakukan di SPPS :

\section{Tabel 4}

Uji Paired Sample T Test

\begin{tabular}{|c|c|c|c|c|c|c|c|c|c|}
\hline & & \multicolumn{5}{|c|}{ Paired Differences } & \multirow{3}{*}{$\mathbf{t}$} & \multirow{3}{*}{ df } & \multirow{3}{*}{$\begin{array}{c}\text { Sig. } \\
\text { (2-tailed) }\end{array}$} \\
\hline & & \multirow[t]{2}{*}{ Mean } & \multirow[t]{2}{*}{$\begin{array}{c}\text { Std. } \\
\text { Deviation }\end{array}$} & \multirow[t]{2}{*}{$\begin{array}{l}\text { Std. Error } \\
\text { Mean }\end{array}$} & \multicolumn{2}{|c|}{$\begin{array}{l}\text { 95\% Confidence Interval } \\
\text { of the Difference }\end{array}$} & & & \\
\hline & & & & & Lower & Upper & & & \\
\hline Pair 1 & $\begin{array}{l}\text { Altman_Z_Score } \\
\text { - Springate }\end{array}$ & 8,21267 & 23,79763 & 2,39175 & 3,46631 & 12,95902 & 3,434 & 98 & 001 \\
\hline Pair 2 & $\begin{array}{l}\text { Altman_Z_Score } \\
\text { - Zmijewski }\end{array}$ & 10,87465 & 24,39658 & 2,45195 & 6,00884 & 15,74046 & 4,435 & 98 & ,000 \\
\hline Pair 3 & $\begin{array}{l}\text { Altman_Z_Score } \\
\text { - Grover }\end{array}$ & 7,96611 & 23,90519 & 2,40256 & 3,19830 & 12,73392 & 3,316 & 98 & 001 \\
\hline Pair 4 & $\begin{array}{l}\text { Springate - } \\
\text { Zmijewski }\end{array}$ & 2,66198 & 1,72793 & 17366 & 2,31735 & 3,00661 & 15,328 & 98 & ,000 \\
\hline Pair 5 & $\begin{array}{l}\text { Springate - } \\
\text { Grover }\end{array}$ &,- 24656 & 1,25306 & 12594 &,- 49648 & ,00336 & $-1,958$ & 98 & 053 \\
\hline Pair 6 & $\begin{array}{l}\text { Grover - } \\
\text { Zmijewski }\end{array}$ & 2,90854 & 2,59949 & 26126 & 2,39008 & 3,42700 & 11,133 & 98 & ,000 \\
\hline
\end{tabular}

Sumber: Hasil Pengolahan Data, 2021

a) Hasil Pengujian Hipotesis Pertama

Berdasarkan hasil perhitungan table 4 di atas yang menunjukan nilai Sig. (2tailed) pada pair 1 yakni antara score model Altman Z-Score dan model Springate adalah sebesar 0.001 , hasil ini menunjukan bahwa probabilitas < 0.05 , hal ini berarti bahwa model Altman Z-Score dan model Springate memiliki perbedaan dalam memprediski financial distress sehingga $\mathrm{H} 1$ dapat diterima dengan tingkat keyakinan $95 \%$.

b) Hasil Pengujian Hipotesis Kedua Berdasarkan hasil perhitungan table 4 di atas yang menunjukan nilai Sig. (2tailed) pada pair 2 yakni antara score model Altman Z-Score dan model Zmijewski adalah sebesar 0.000 , hasil ini menunjukan bahwa probabilitas < 0.05 , hal ini berarti bahwa model Altman Z-Score dan model Zmijewski memiliki perbedaan dalam memprediski financial distress sehingga $\mathrm{H} 2$ dapat diterima dengan tingkat keyakinan $95 \%$.

c) Hasil Pengujian Hipotesis Ketiga
Berdasarkan hasil perhitungan table 4 di atas yang menunjukan nilai Sig. (2tailed) pada pair 3 yakni antara score model Altman Z-Score dan model Grover adalah sebesar 0.001, hasil ini menunjukan bahwa probabilitas < 0.05, hal ini berarti bahwa model Altman Z-Score dan model Grover memiliki perbedaan dalam memprediski financial distress sehingga $\mathrm{H} 3$ dapat diterima dengan tingkat keyakinan $95 \%$.

d) Hasil Pengujian Hipotesis Keempat Berdasarkan hasil perhitungan table 4 di atas yang menunjukan nilai Sig. (2tailed) pada pair 4 yakni antara score model Springate dan model Zmijewski adalah sebesar 0.001, hasil ini menunjukan bahwa probabilitas < 0.05, hal ini berarti bahwa model Springate dan model Zmijewski memiliki perbedaan dalam memprediski financial distress sehingga $\mathrm{H} 4$ dapat diterima dengan tingkat keyakinan $95 \%$.

e) Hasil Pengujian Hipotesis Kelima Berdasarkan hasil perhitungan table 4 di atas yang menunjukan nilai Sig. (2- 
tailed) pada pair 5 yakni antara score model Springate dan model Grover adalah sebesar 0.053, hasil ini menunjukan bahwa probabilitas > 0.05 , hal ini berarti bahwa model Springate dan model Grover tidak memiliki perbedaan dalam memprediksi financial distress sehingga H5 ditolak.

f) Hasil Pengujian Hipotesis Keenam Berdasarkan hasil perhitungan table 4 di atas yang menunjukan nilai Sig. (2tailed) pada pair 6 yakni antara score model Grover dan model Zmijewski adalah sebesar 0.000, hasil ini menunjukan bahwa probabilitas < 0.05, hal ini berarti bahwa model Grover dan model Zmijewski memiliki perbedaan sehingga $\mathrm{H} 6$ dapat diterima.

\section{Analisis Uji Keakuratan Model Prediksi}

Setelah melakukan perhitungan tingkat keakuratan dengan membagi perusahaan menjadi 2 kriteria yakni perusahaan yang diindikasikan mengalami financial distrees dan perusahaan yang tidak mengalami financial distrees dengan kriteria sebagai berikut:

1.Perusahaan yang mengalami financial distress selanjutnya akan disebut dengan perusahaan kategori 1 dengan kriteria sampel:

a. Perusahaan memiliki laba bersih negatif selama 3 kuartal berturutturut selama periode Q2 2018-Q2 2020.

b. Perusahaan berasal dari sektor yang sama yakni Sub Sektor Logam dan Sejenisnya.

2. Perusahaan yang tidak terindikasi financial distress, selanjutnya akan disebut sebagai perusahaan kategori 2, dengan kriteria :

a. Perusahaan tidak memiliki laba bersih negatif selama 3 kuartal berturut-turut selama periode Q2 2018-Q2 2020.

b. Perusahaan berasal dari sektor yang sama yakni Sub Sektor Logam dan Sejenisnya.

Setelah dilakukan perhitungan dengan rumus keakuratan seperti berikut :

Keakuratan $=\frac{\text { Jumlah Prediksi Benar }}{\text { Jumlah sampel }} x 100 \%$

Maka diperoleh hasil seperti dibawah ini:

Tabel 5

Hasil Perhitungan Keakuratan

\begin{tabular}{lll}
\hline No & Model Prediksi & Tingkat Akurasi \\
\hline 1 & Altman Z-Score & $36,36 \%$ \\
2 & Grover & $81,82 \%$ \\
3 & Zmijewski & $63,64 \%$ \\
4 & Springate & $54,55 \%$ \\
\hline
\end{tabular}

Sumber: Hasil Pengolahan Data,2021

Perhitungan analisis keakuratan prediksi financial distress dengan model Altman Z-Score, Grover, Zmijewski dan Springate, menunjukan bahwa tingkat akurasi yang tertinggi dimiliki oleh model Grover dengan nilai $81.82 \%$ dan disusul oleh Zmijewski dan Springate dengan nilai masing-masingnya adalah $63.64 \%$ dan $54.55 \%$ dengan tingkat akurasi terendah dimiliki oleh model Altman Z-Score dengan nilai $36.36 \%$.

\section{Pembahasan}

Financial distress salah satu
metoda dalam menghitung dan menganalisis kinerja keuangan dengan menggunakan data akuntansi atau data keuangan. Teory signal dalam financial distress memberikan signal kepada para manager tentang informasi yang akan diambil berkaitan dengan kondisi keuangan perusahaan saat ini agar dapat diambil kebijakan dan strategi yang tepat kedepannya. Sehingga manager dapat menentukan strategi yang tepat dalam menentukan kebijakan yang berkaitan dengan kondisi keuangan perusahaan dan juga bisa memberikan signal yang tepat kepada para investor terhadap kondisi 
keuangan perusahaan. Perkembangan model prediksi kebangrutan memberikan prediksi dan nilai keakuratan yang berbeda-beda, dan memberikan alternative bagi manajemen perusahaan memilih metode yang sesuai dengan sektor masing-masing.

Jika dibandingkan dari komponen perhitungan masing-masing model yang digunakan dalam memprediksi financial distress maka model Altman Z-Score dan model Zmijewski lebih komprehensif didalam memprediksi kebangkutan dikarenakan tidak hanya mempertimbangan pada jumlah aset yang dimiliki oleh perusahaan, namun juga melihat bagaimana kondisi liabilitas dan ekuitas perusahaan, karena untuk memprediksi kondisi keuangan perusahaan tidak hanya dilihat dari asset atau kekayaan yang dimiliki perusahaan namun juga harus melihat efektifitas penggunaan utang dan kemampuan perusahaan memenuhi kewajibannya serta bagaimana memanfaatkan asset dan ekuitas perusahaan dalam memperoleh keuntungan. Sehingga kedua metode ini menjadi metode yang dapat dipertimbangan perusahaan untuk memprediksi dan melihat indikasi dari kinerja keuangan yang terjadi.

\section{SIMPULAN}

1. Berdasarkan hasil uji Paired Sample TTest antara model Altman-Springate, Altman-Zmijewski, Altman Grover, Springate-Zmijewski, GroverZmijewski mengatakan bahwa model ini memiliki perbedaan yang signifikan dalam memprediksi financial distress sebuah perusahaan. Namun dari hasil perhitungan juga dikatakan antara model Springate dan Model Grover memiliki kesamaan dalam menghitung financial distress, hal ini dibuktikan dengan tingkat Sig. (2-tailed) probilitasnya $>0.05$.
2. Berdasarkan perhitungan analisis keakuratan prediksi financial distress dengan model Altman Z-Score, Grover, Zmijewski dan Springate, menunjukan bahwa tingkat akurasi yang tertinggi dimiliki oleh model Grover dengan nilai $81.82 \%$ dan di susul oleh Zmijewski dan Springate dengan nilai masing-masingnya adalah $63.64 \%$ dan $54.55 \%$ dengan tingkat kaurasi tereendah dimiliki oleh model Altman Z-Score dengan nilai $36.36 \%$.

3. Berdasarkan model prediksi yang digunakan dapat disimpulkan bahwa model yang lebih baik digunakan dalam melakukan analisis financial distress adalah model Altman Z-Score dan model Zmijewski dikarenakan model ini tidak hanya berfokus pada jumlah aset yang dimiliki oleh perusahaan, namun juga melihat bagaimana kondisi liabilitas dan ekuitas perusahaan, hal ini diperlukan untuk melihat apakah perusahaan dapat mengelola liabilitas dan ekuitas dengan baik dan pengelolaan liabilitas juga berpengaruh akan kemampuan perusahaan dalam membayarkan kewajibannya, dimana kemampuan perusahaan dalam membayarkan kewajiban merupakan indikator utama yang dilihat dalam analisis financial distress.

Berdasarkan kesimpulan yang telah dikemukakan, maka penulis dapat mengajukan saran-saran sebagai berikut:

1. Dalam penelitian ini hanya digunakan 4 model analisis financial distress sehingga pada penelitian selanjutnya diharapkan dapat menambah model atau menggunakan model prediksi lain dalam menganalisis prediksi

2. Dalam penelitian ini hanya memprediksi financial distress pada sub sektor logam dan sejenisnya, sehingga pada penelitian selanjutnya diharapkan dapat menerapkannya pada sektor lain seperti sektor properti, 
manufaktur, perbankan, dan lain sebagainya. Penelitian selanjutnya dapat menggunakan kriteria financial distress yang berbeda.

3. Dalam penelitian ini hanya menggunakan periode penelitian kuartal, untuk penelitian selanjutnya diharapkan dapat menggunakan periode yang lebih panjang sehingga dapat melihat perubahan lebih banyak tentang kinerja perusahaan.

4. Agar perusahaan dapat mengelola asetnya dengan baik, karena dengan mengelola aset dengan baik maka perusahaan dapat menjaga nilai aset tetap tinggi, sehingga manajemen aset tetap baik dan stabil.

5. Agar perusahaan menentukan tujuan pengalokasian yang tepat, pengalokasian dana yang tepat diharapkan dapat meminimalisir kerugian yang mungkin akan di dapatkan oleh perusahaan.

\section{DAFTAR PUSTAKA}

Abrar, Thea Fathanah. 2020. "Efek Covid-19, WTO Sebut Perdagangan Global Anjlok 18,5\%." Www.Cnbcindonesia.Com.

Beams, Floyd A. 2015. Akuntansi Lanjutan. Delapan. Jakarta Barat: Indeks.

Fauzia, Mutia. 2019. "IMF: Dampak Perang Dagang Ke Ekonomi Dunia Bisa Setara Ekonomi Swiss." Www.Kompas.Com.

Hantono. 2019. "Memprediksi Financial Distress Dengan Menggunakan Model Altman Score, Grover Score , Zmijewski Score ( Studi Kasus Pada Sub Sektor Perusahaan Perdagangan Besar )." 9(April): 112.

Harahap Syafitri, Sofyan. 2013. Analisis Krintis Atas Laporan Keuanga. Kesebelas. Rajawali Pers, Jakarta.

Harmony. 2020. "Inilah Pengertian Laporan Keuangan Sesuai PSAK,
Fungsi Dan Contoh Praktisnya." Www.Harmony.Co.Id.

Junaedy, Intan, And Yanti. 2019. "Uji Beda Karakteristik Terhadap Perusahaan Financial Distress Dan Non-Financial Distress." Jurnal Multiparadigma Akuntansi I(3): 927-36.

Koesno, Dhito. 2020. "Update Corona Dunia 2 Desember 2020: Total Kasus Mencapai 64,1 Juta." Www.Tirto.Id.

Mulyani, Luh, Ni Luh, Gede Erni, And Made Arie Wahyuni. 2018. "Analisis Perbandingan Ketepatan Prediksi Finan- Pada Perusahaan Retail Yang Terdaftar Di Bursa Efek Indonesia Periode 2015-2017 )." Jimat (Jurnal Ilmiah Mahasiswa Akuntansi) Universitas Pendidikan Ganesha, 9: 139-50.

Sari, Ika Puspita. 2020. "Indeks Sektor Industri Dasar Dan Kimia Anjlok 21,24\%, Begini Kata Analis." Www.Kontan.Co.Id.

Sugiyono. 2018. Metodepenelitian Kuantitatif Kualitatif Dan $R \& D$. Bandung: Alfabeta.

Supriati, Diana, Icuk Rangga Bawono, And Kusriyadi Choirul Anam. 2019. "Analisis Perbandingan Model Springate, Zmijewski, Dan Altman Dalam Memprediksi Financial Distress Pada Perusahaan Manufaktur Yang Terdaftar Di Bursa Efek Indonesia." Journal of Applied Business Administration 3(2): 258-70.

Ugene F. Brigham, Joel F. Houston. 2014. "Essentials Of Financial Management Dasar-Dasar Manajemen Keuangan."

Yuliastary, Etta Citrawati, And Made Gede Wirakusuma. 2014. "Analisis Financial Distress Dengan Metode Z-." 3: 379-89. 